\title{
Rilke's Duino Elegies and Sonnets to Orpheus
}

\section{Citation}

Ryan, Judith. 2015. Rilke's Duino Elegies and Sonnets to Orpheus. In 1922: Literature, Culture, Politics, edited by Jean-Michel Rabaté, 29-42. Cambridge: Cambridge University Press.

\section{Published Version}

10.1017/cbo9781139629102.004

\section{Permanent link}

http://nrs.harvard.edu/urn-3:HUL.InstRepos:32186503

\section{Terms of Use}

This article was downloaded from Harvard University's DASH repository, and is made available under the terms and conditions applicable to Open Access Policy Articles, as set forth at http:// nrs.harvard.edu/urn-3:HUL.InstRepos:dash.current.terms-of-use\#OAP

\section{Share Your Story}

The Harvard community has made this article openly available.

Please share how this access benefits you. Submit a story.

\section{Accessibility}




\section{Judith Ryan: Rilke's Duino Elegies and Sonnets to Orpheus}

I would like to begin this essay on Rilke and 1922 with a thought experiment. Let us suppose that at the end of Rilke's Duino Elegies, we were to find a statement something like the following:

Although the title indicates one debt of gratitude underlying this sequence of elegies, the plan and a good deal of the symbolism were suggested by Rudolf Kassner's book, Von den Elementen der menschlichen Größe (recently reissued by the Insel Verlag along with his earlier book Der indische Gedanke). Indeed, so deeply am I indebted, Mr Kassner's books will elucidate the difficulties of the poem much better than notes of mine could do; and I recommend them (apart from the great interest of the books themselves) to any who think such elucidation of the poem worth the trouble. To another author I am also indebted in general, one who has influenced many generations of readers profoundly; I mean Goethe, especially his elegy "Euphrosyne." Anyone familiar with this great poem will recognize in the elegies certain references to the task of mourning. ${ }^{1}$

Of course, Rilke did not write such a note. I've proposed that we imagine it, however, in order to suggest that the Duino Elegies are not quite as distant from The Wasteland as one might think at first glance. Like Eliot's long poem, Rilke's elegies are a learned work, one that relies on numerous poetic and philosophical sources. In this essay, I will focus primarily on the two authors whose names I have used in my fictitious note.

Given that Rilke wrote most of the Duino Elegies and the entire sequence of Sonnets to Orpheus during periods of intense solitude when his only other occupations were extensive reading and letter-writing (in which he tends to comment on his reading), the intertextual

1 This note is adapted from T. S. Eliot's prefatory note to his annotations of The Wasteland (Eliot, p. 70). 
character of the works is not surprising. Rilke felt very strongly that isolation from the world would be the best way to nourish the ambitious project he had set himself in the Elegies, and we repeatedly see him on the look-out for places where he could retreat from social obligations. Princess Marie von Thurn und Taxis's castle in Duino in 1912, Hertha Koenig's apartment in Munich in 1913, Schloss Berg am Irchel 1920/21, and his rented stone house, the Château de Muzot in 1922, were places where he found such solitude. Yet only in the first and the last of them did he make real progress on the long poem he had assigned himself to write. Ten years separated the two bursts of writing. Still, a painting by Picasso that he studied every day in the Munich apartment did eventually make its way into the text. The title of the whole, Duino Elegies, was a product of the very last phase in the gestation of his multi-part poem.

In the final days of January and the early days of February 1922, a complex process kept the completion of the Elegies intertwined with the beginning of the Sonnets. Of course we have always known that the two works belong together. Nonetheless, I will be arguing here that the connection is tighter than has previously been acknowledged. ${ }^{2}$ An essay of this length can hardly do justice to such challenging works. For this reason, I will focus on two fundamental issues: the extent to which the First World War is entangled with the two poems and the influence Goethe and Kassner on both sequences of poems. Goethe's elegy "Euphrosyne" is sometimes mentioned in connection with Rilke's Duino project, but it is scarcely known how thoroughly the poem permeates not only his Elegies, but also his Sonnets. ${ }^{3}$ As for Rudolf Kassner, the Eighth Elegy is explicitly dedicated to him; but again, his pervasive presence in Rilke's poetry from 1912-1922

2 The 1996 edition of Rilke's works positions the Elegies at the end of "poems 1910-1922" and begins a new section with the "Sonnets to Orpheus and the latest poems." (Engel, vol. 2)

3 Two of Rilke's biographers say more about the poem than we find in most readings of the Elegies, but they hesitate to follow up the connections they suggest: see Prater, 206 and Freedman, 328-329. 
has not been adequately traced. ${ }^{4}$ Like Goethe's "Euphrosyne," Kassner's social philosophy functions both as a scaffold for the Elegies and a hinge that keeps that keeps that ambitious work connected with the serendipitous Sonnets to Orpheus. Along the way, I will consider Rilke's long-standing interest in the sonnet form and his prolific translations of sonnets from several different languages in the period leading up to what I will call "the Duino project."

To understand the gestation of Rilke's Duino Elegies, we need first to focus on the effects of World War I. Although Rilke's health allowed him to escape service at the front, his experience of the war years was psychologically devastating. When he finally returned to the Elegies in the first months of 1922, the war was still not far from his mind. It makes sense, then, to review Rilke's responses to the Great War from the beginning. In the opening days of the conflict, he felt—as many people did at the time — that war might shake them into action. By November 1914, he saw things differently: "In the first days of August the manifestation of the war, the war god, gripped me," but now he is aware only of "a spirit of affliction" (letter of 6 November, 1914; AB II, p. 15). By mid-February 1916, he had been conscripted and assigned to the Austrian War Archive, where he rapidly became distressed by the need to create positive accounts of military engagements, even when the war was not going well. The worst aspect of his work at the archive was that it interrupted his own writing, which had been pouring forth in "a preliminary storm of work," that included both individual poems and a substantial number of translations from Michelangelo's sonnets (letter of 6 November 1914, AB, p. 62.)

Fortunately his health soon released him from the war work, and Rilke moved to Munich. While there, he received a letter from one of his former teachers at the military academy he had attended as an adolescent. At first Rilke did not respond to General-Major von Sedlakowitz, but

4 Bishop's observation that "echoes of Kassner's ideas can be heard throughout the [Elegies]" (p. 161) is something of an exception. 
after a brief hesitation, he wrote him a long letter spelling out in detail the torments he had experienced at the school (letter of 9 December, 1920, AB II, pp. 200-206). Excruciating to read, this account shows how much Rilke still bore the mark of that suffering. At the end of the war, Rilke experienced a series of displacements. In September 1919, his Austrian passport became invalid: he was now a stateless person. Because he was born in Prague, he applied for a Czech passport. ${ }^{5}$ Bureacratic processes were complicated and lengthy, however, and even with a temporary visa for Switzerland, he still had no settled domicile. Financial problems exacerbated his distress, since the allowance from his publisher was paid in German marks, a currency increasingly threatened by inflation. For Rilke, the war seemed to persist into January 1922, when he wrote to Simone Brüstlein: "The war, the war is still everywhere, everywhere everything is still interrupted, separated, blown apart, and lies there as one piece among others [...]" (Letter of 13 January, 1922, Briefe an schweizer Freunde, p. 197). Yet he does make a crucial distinction between the destruction and fragmentation of the present day and ancient fractures such as the temple walls at Karnak, Sappho's poetic fragments, the bridge of Avignon (ibid., p. 197). We catch glimpses of this view in the Elegies (especially the Tenth) and certain of the Sonnets.

Looking back just a few weeks after he had finished the Duino project, he realized that his choice of genre had been even more appropriate than he had known at the outset of the project in 1912. The poems are elegies, he explained in a letter of March1922, "the more so in that the course of the war has destroyed the protective walls of that wonderful Adriatic castle [...] almost to the last piece of timber" (letter of 17 March 1922 to Countess Margot Sizzo-Noris Crony, AB II, pp. 336-67).

5 Czechoslovakia had asserted its independence from the Austro-Hungarian Empire on October 28, 1918, and on November 14, 1918, it had become a republic. 
His attempt at the elegiac form in 1912 had been in large measure the result of an initiative on the part of his publisher. Horrified by his inadequate acquaintance with canonical German literature, Anton Kippenberg and his wife Katharina set about initiating Rilke into their favorite texts. It was mainly Katharina who conducted the reading course. Among the poems to which she introduced him, Goethe's elegy "Euphrosyne" was the most successful in bringing about Rilke's “conversion” to his illustrious predecessor. ${ }^{6}$ On a visit to Weimar in 1911, Rilke made a special pilgrimage to Goethe's garden house, where a memorial to the young actress "Euphrosyne" could still be seen. ${ }^{7}$ In a letter to a friend to a friend, he wrote: "This time I really saw Weimar, the Goethe archive, the 'garden house,' the Widow's Palace and Tiefurt House; [...] Goethe was gracious to me for the first time-you know that I kept no altar for him" (letter to Hedda Sauer of 28 September, 1911, AB I, 314).

Goethe's "Euphrosyne" (1799) is a mourning poem in memory of a young actress, Christiane Becker, whose last acting role had been that of the grace "Euphrosyne" (meaning mirth or merriment), the daughter of the muse of memory, Mnemosyne. Appropriately for a memorial text, the piece is cast in German elegiac verse, an adaptation of the meters used by the elegists of classical antiquity. News of the actress's death reached Goethe while he was traveling in the Swiss Alps, and the mountainous landscape plays a prominent role in the poem. Goethe looks back to the beginning of her acting career, when, still a child, she had played the part of the boy Arthur in Shakepeare's King John. Frustrated by her hesitant acting, Goethe took over the role of Hubert as he threatens to blind the boy with a red-hot poker and rendered it in all its terror. In response, Christiane fell to the ground so convincingly that Goethe thought she had to their own passionate faith in Goethe," p. 72.

7 It has now been moved to the old cemetery in Weimar (Paulin, p. 61). 
actually lost consciousness and might have been seriously hurt. He finally realized that she was only acting when she lifted up her head and asked for water. In the elegy, he imagines an even more striking event when she seems to return from the dead and speak to him. Sensing her presence during his mountain journey, the speaker asks: "What goddess approaches me? And which of the muses/ seeks the true friend even in these awful abysses?" A number of similar questions punctuate the poem.

I believe that a dim recollection of such questions from Goethe's "Euphrosyne" was the trigger for Rilke's First Elegy. Clambering on the cliff face below Castle Duino one January day, Rilke seemed to hear a voice uttering a line of verse: "Who, if I cried out, would hear me from among the orders of angels?" Later that month, he told Marie von Thurn und Taxis that he had received the opening line of the poem "by dictation." Distinct traces of Goethe's elegiac meters (distichs consisting of dactylic hexameters and "pentameters" made up of two sets of two and a half feet, the second set of which is predominately dactylic) can be heard in the Duino Elegies, though Rilke's handling of the form is a free adaptation that does not strictly observe the meter and shortens occasional lines. The effect Rilke achieves suggests that the modern period has access only to a broken form of the original meters. Only the fourth and the eighth elegies, which are in regular Shakespearean iambic pentameters, ${ }^{9}$ diverge from the general pattern. In contrast to Goethe's "Euphrosyne," where the dead woman responds to the poet's question in the same fluent verse as the famous poet himself, ${ }^{10}$ Rilke's First Elegy makes abundantly clear that no answer is possible to the poet's summoning cry.

8 Cf. the C.W. poems written in Schloß Berg in Switzerland.

9 Katharina Kippenberg also introduced Rilke to at least two works of Shakespeare, notably King John (because of its connection with "Euphrosyne") and The Tempest (see Rilke's poem "The Spirit Ariel”).

10 Rilke regarded his own poem as a kind of heightened version of Goethe's "Euphrosyne," in which he had first discovered the "conflation of youth and death" (Freedman, p. 329). 
The verse alone is not the only trace of Goethe's poem in the Duino Elegies. In terms of theme, the notion of premature death figures throughout the sequence. The First Elegy conjures up strange sounds: "Voices, voices." Indeterminate and difficult to locate, these voices may just be part of a flow of wind that reaches us somehow like a message from the prematurely dead. The verb Rilke uses here is "rauschen": to rustle, ripple, or make a rushing sound; it is drawn from the vocabulary of German Romanticism, where nature continually speaks through such ambiguous noises, interpretable only by poets. Here in Rilke's First Elegy, the speaker tries to imagine the sensory impressions of the early dead, torn away from the familiar world and introduced into a strange new environment. The elegy ends by reminding us that this is precisely how music originated, in the song of Linos, a Greek demigod sometimes regarded as a predecessor of Orpheus. The idea that music arises from the act of mourning is a leading theme throughout the entire sequence of Duino Elegies. Like Goethe's "Euphrosyne," these poems are also meditations on the role of art as a form of memorial.

The Second Elegy, written in February 1912, picks up additional elements from Goethe's "Euphrosyne." One of these is the mountainous landscape in which Goethe first heard of Christiane's death. The alpine trip establishes a natural setting that allows him to contrast "unformed" nature with the aesthetic forms of theater, the genre in which the young actress had excelled. Craggy, asymmetrical landscape was connected with the concept of the sublime, which both Burke and Kant associated with fear. "Secret crevasses and gorges," "terrifying crags" or "awful abysses" in Goethe's elegy are elements that seem to find a poetic transformation in Rilke's bold description of the angels as "mountain ridges, morning-red crests/ of all of 
creation." ${ }^{" 11}$ In other parts of Duino Elegies, mountainous nature reappears, as in the metaphor of the wanderer who brings back a handful of earth or a blue gentian flower from the mountain slope in the Ninth Elegy. Perilous landscape is present, finally, in the Tenth Elegy, where the "newly dead" youth arrives at a valley in the foothills of mountains. He has been led there by a quasi-mythical being called a Lament, from whom he must now part ways. Alone, he climbs upward, into "the mountains of primal suffering." That suffering should take the form of mountains may be another recollection of Goethe's "Euphrosyne." Certainly we find here once again the conjunction of unformed nature and the aesthetic shape of poetry.

The loss of a loved one is another link between "Euphrosyne" and Duino Elegies. Goethe's love for Christiane is palpable. In Rilke's long poem the theme of love is everywhere, yet there is never a moment when the text settles on a specific object of affection. Instead, the elegies draw on a motif that Rilke had adopted from other poetic precursors, notably Friedrich Klopstock: the "future beloved." In a number of texts that Rilke composed between 1910 and 1914 but did not publish during his lifetime,${ }^{12}$ giving it a more complicated form in an untitled poem that begins "Beloved, lost from the outset" (1913/14). A related rendering of the motif occurs in one of the Sonnets to Orpheus: "Be ahead of all parting, as if it were behind you,/ like a winter just passing away" (Sonnets, II, xiii). In the 1913/14 text, the speaker asks "what tones you care for"- as if some special melody or words could bring forth the elusive loved one. Perhaps for Rilke the one who never appears is a poem rather than a person.

11 Similarly striking images in the second section of this elegy recall Rilke's poem sequence about the Virgin Mary, Das Marien-Leben (composed in 1912 in Duino just before Rilke's breakthrough to the Elegies but not published until 1913).

12 He regarded these texts as odd and somehow unfinished (some but not all were indeed fragments). See his letter of 20 June, 1914 to Lou Andreas-Salome about a "curious poem" that he has just written ("Turning Point") describing the turn "which must indubitably occur if I am to live" (AB 1,506). 
In the Elegies, human life is presented as transient and fragile. Even the ecstatic consummation of lovers is tenuous. "For we, when we feel emotions, vanish away" (Second Elegy): our emotions evaporate even as we experience them. An emblem of this fragility is encapsulated in the delicate depiction of human figures on Attic monuments, whose very gestures seem so ethereal that a touch of the hands appears to leave no trace. Lovers figure in different guises in the Elegies, among them the boy in early puberty who has not yet experienced an actual erotic relationship (Third Elegy), the lovers who court danger by constantly coming to close to boundaries (Fourth), the blissful lovers on the acrobats' mat (Fifth), and the lovers who wear out the threshold (Ninth). In the final elegy, lovers hold one another, "aside, earnestly, in the sparse grass." In the "wide landscape of the Laments" that occupies a substantial part of that elegy, however, the lovers are replaced by a different couple: the Lament and the boy who died young. Like the figures on Attic monuments, the two interact with restraint: "He is moved by the way she bears herself. Her shoulders, her neck -, perhaps/ she is of noble origin."

The landscape through which the Lament leads the youth is a reconfiguration of the Nile landscape that Rilke had seen during his trip to Egypt in 1911. As night falls, the boy and his companion tread more softly until they see a large monument rising up, "the grave monument that watches/ over everything, a brother to the one on the Nile,/ the noble Sphinx —: the visage/ of the secret chamber." The designation of the Egyptian sphinx as a grave monument is significant, as it is precisely this term, "Grab-Mal," that Rilke uses in the subtitle of his Sonnets to Orpheus, written in memory of the young girl Wera Ouckama Knoop. ${ }^{13}$ Yet at the same time, the Sonnets are also a monument to Orpheus, the ancient poet, originator of the art of song. In 
this context, Wera becomes a kind of Eurydice figure. ${ }^{14}$ In a similar fashion, we might also say that the youth's climb into the mountains at the end of the Tenth Elegy is a mirror-image of Orpheus' descent into the underworld in his attempt to rescue his beloved Eurydice.

The Sonnets to Orpheus, in other words, are not poems that simply arose as Rilke completed his Elegies. They are an intimately related work. Although he considered including his poems and fragments from 1910-14 in the same volume as the Elegies, he also contemplated the possibility of including the Sonnets instead (Letter to Kippenberg of 23 February, 1922). In the end, the two works were published separately.

If the Elegies are a "monument" to the war-ravaged castle of Duino and the Sonnets a monument to the young dancer Wera, the two works are connected by the over-arching theme of poetry itself as a monument. In the remarkable Fifth Elegy, street performers create a temporary, if repeatedly renewed monument in the form of a human pyramid. Their balancing feat is described as "laid on like a plaster, as if the suburban heaven had wounded the earth there." This elegy, written on February 14, 1922 and dedicated to Hertha Koenig, was inspired by Picasso's painting, "Saltimbanques," which hung on the wall of her apartment where Rilke lived in summer 1915. The painting shows a family of acrobats standing together in a triangular arrangement, with a young girl off to the right side. In contrast, the Fifth Elegy depicts acrobats in motion, forming a rose shape that repeatedly "blossoms and fades" as the participants leap up onto the human pyramid and then back down onto the mat in what is described as a "tree of collectively constructed movement." If we read the Elegies and Sonnets in the order of their composition, a different "tree" had already been created in the first of the Sonnets to Orpheus,

14 Alan Keele calls Sonnet II, xxviii a "Eurydice sonnet" (Keele, p. 220). 
written between the $2^{\text {nd }}$ and $5^{\text {th }}$ of February 1922 . This is the metaphorical tree of Orpheus' song: "There rose a tree. O purest of transcending/O Orpheus sings! O tall tree in the ear!" Unlike the impermanent tree of the transient acrobats, the tree of Orpheus' singing is a potent spell that inhabits every part of nature. This conception of Orpheus' song as ever latent in the world is the reason why, just a few poems later, we are exhorted not to erect a monument to the primal singer ("Erect no monument. Just let the rose/ bloom every year to celebrate him. For it is Orpheus. His metamorphosis/ in one thing and another." (Sonnets I, v). Not unlike the imagined grave monument of the Tenth Elegy, the song of Orpheus is nonetheless an imagined place of worship: a "temple in the ear" (Sonnets I, i). ${ }^{15}$

The Elegies and Sonnets have much else in common as well. Both had begun in an unexpected storm of creativity: Rilke uses the word "hurricane" to describe the overwhelming nature of the two experiences (letters to Lou and to Kippenberg respectively, AB II, 311 and 313). Large issues in the Elegies reappear in the Sonnets: the nature of transcendence, the limitations of human consciousness, our relation to nature, how death figures in our understanding of life, and the relation of the divine to human suffering. Secularization underlies the attempt to recreate a new conception of angels in the Elegies as well as the revival of Orpheus in the Sonnets. Modernity is addressed in the Elegies through a metaphor that presents electric power stations as an expression of the age (Seventh Elegy) and in the Sonnets by a poem deploring the machine (Sonnets, II, x); the inflationary economy is even mentioned in Sonnets II, xix. A group of motifs, some of them seemingly familiar from poetic tradition-night, wind, landscape, lovers - appear in highly idiosyncratic forms in both works. ${ }^{16}$ Throughout the elegies, human beings are set within another space that remains only partially perceptible, mainly

15 Rilke's translation of Paul Valéry's essay "Eupalinos ou l'architecte” may have also reinforced this idea. 
through the action of wind and the overwhelming manifestation of night. The term "Weltraum" (outer space) acquires an unusual inflection in the elegies, signifying not only the space in which we live - the air that surrounds us — but also a larger composite into which our own inner selves are enfolded, making a single entity out of the earth's atmosphere, outer space, and the human psyche. Rilke calls this new entity "Weltinnenraum." In the Sonnets, wind signifies inspiration, as it does in much traditional poetry, but also the voice of Orpheus as it has been absorbed by nature: the breath of Orpheus augments natural space (Sonnets II, xxix). Breath itself is an "invisible poem" (Sonnets, II, i). Wind is connected with both the demigod Linos in the First Elegy, and Orpheus, the god of original song in the Sonnets.

We have seen that the idea of elegy and the echoes of classical elegiac meters is a driving force in most of the Elegies. What motivated the sudden upsurge of sonnets at the tail end and in the aftermath of the Elegies? Rilke had long been interested in the sonnet form, and many of the poems in his New Poems were sonnets or variations of sonnets. With help from friends who knew English, he had translated Elizabeth Barrett-Browning's Sonnets from the Portuguese and published them in 1908; his translations of the sonnets of Louise Labé, which he had been working on in 1912-13, were published in 1918; and just before his assignment to the Austrian War Archive in 1916, he had been in the midst of an ambitious project of translating Michelangelo's sonnets. Only a few of the Michelangelo translations, which he had hoped to render as authentically as possible into German (letter to Ellen Delp, 4 January, 1922, AB II, 292), were published during his lifetime. Rilke's extensive experience with the sonnet form, including sonnets from languages like French ${ }^{17}$ and Italian, accounts at least in part for Rilke's

16 Two fragmentary poems composed in Duino during spring 1912 show Rilke experimenting with this motif. He was to work more explicitly with it in late 1913, while he was reading Friedrich Klopstock's odes (Ryan, pp. 138142). 
extraordinarily light handling of the form in the Sonnets to Orpheus. It is no wonder that these poems seemed to spring forth unbidden.

Another feature of the sonnet form is also relevant: its dependence on a turn of thought that—at least in French and Italian — tends to occur after the first two quatrains. Rilke had long been interested in writing poems that turned on an internal pivot. During the gestation of the Elegies, however, he came to believe that his own life was in need of such a turning-point. He understood his poem "Turning Point" of 1915 as pointing to a turning he hoped might happen in his own life. For the structure of the Elegies, Rilke's recollection of a statement by Rudolf Kassner: "The path from intimacy to greatness passes through sacrifice" forms an important expression of a turning process in human development in general.

Although only the Eighth Elegy is specifically dedicated to Kassner, it is difficult to overestimate the significance of the social philosopher for the entire project. Indeed, Kassner was present among a select group of friends whom Marie von Thurn und Taxus had invited to Castle Duino in December 1911, just before Rilke began his work on the Elegies. At first a little intimidated by Kassner, Rilke came to know him well, notably during a period of three years (1916-1919) when both were living in Munich (Chapple). Following Rilke's departure from Germany, they remained in correspondence. Kassner's On the Elements of Human Greatness (1911) made an overwhelming impression on Rilke. What he saw in it, above all, was an "incredible Coming-to-its-Senses of certain concepts which had been drunk with sleep, so to speak, for centuries." (Letter to Marie von Thurn und Taxis, 2 June, 1911, AB I, 307).

17 In December 1921, Rilke was reading other French poets, including Baudelaire, Verlaine, Mallarmé. Muzot was located in French-speaking Switzerland, and during the 1920s, especially in 1924/25, Rilke began writing poems of his own in French. 
Kassner's discussion of the "hero" left a strong mark on Rilke's poetry, notably in the Third and Sixth Elegies. In another way as well, Kassner's thought informs the Elegies and Sonnets. Rilke had also read Kassner's The Indian Idea (1913); it was republished with the 1911 essay in a single slim volume in 1921. In the 1913 essay, Kassner comments on divergent approaches to numbers in Indian and European culture. "The secret of Indian mathematics and logic is that it operates without zero, or rather places this not at the midpoint between hot and cold, but nowhere at all" (Kassner, p. 16). This may explain such mystifying phrases as „Nirgends ohne Nichts“" (Nowhere without Nothing) in the Eighth Elegy or "Ein Hauch um Nichts" (A breath about Nothing) in Sonnets I, iii.

Structurally, the Elegies work through a somewhat loose train of argument that depends substantially on Kassner's thought. Whereas the speaker of the First Elegy had tried to summon an angel, the Seventh Elegy takes a striking turn with its opening exclamation, "Wooing no more!" Now the speaker now bends his attention to earth; in so doing, he revises his thoughts about the purpose of poetry. What poetry does, he claims, is to transform the earth as we know it into images: in order to "build it inwardly, with pillars and statues, yet greater!" Our imaginative capacity, he recognizes, is grander than anything we could learn from the angel. The Eight Elegy (dedicated to Kassner) continues this idea of a new turning toward earth. Throughout the elegies, human beings are set within another space that remains only partially perceptible, mainly through the action of wind and the overwhelming manifestation of night. Unlike animals, who see into "the open," human consciousness has narrower access to the wholeness of things.

Echoing the injunction "Wooing no more!" of the Seventh Elegy, the third of the Sonnets to Orpheus sets forth a similar mandate: "not desire, not wooing." Images of turning recur in many of the sonnets, for example in the image of balls in flight: "Only the balls. Their splendid 
arcs" (Sonnets, II,viii). The creative mind, one sonnet suggests, "loves nothing so much as the turning point in the swing of the figure" (II, xii), where the term "figure" refers to a pattern created by movement. As a dancer, young Wera provides a model for the connections our eyes and minds make as a dance unfolds. She is apostrophized as "Dancer, o you displacement of everything transient in motion" (II, xviii). The notion of transformation by the mind's eye is introduced in the Seventh Elegy as part of a developing thought process, but in the Sonnets, transformation is everywhere: it is the very essence of this poetry. Just as praise marks the turning point of an unfolding process in the Seventh and Ninth Elegies ("Praise the world to the angel"), the entire posture of the Sonnets is one of "praising." The increased airiness of the Sonnets is part of the work's emphasis on imagination, a process aided by the many gaps theat seem to open up in the poems.

The entire Duino project (the Elegies and Sonnets together) undertakes a complex exploration of death and memorialization in both ancient traditions and modern understanding. Monuments, tombs, sarcophagi, and small objects sometimes often placed with the bodies of the dead - the "finger ring, brooch, and jug" of Sonnets, I, vi, for example — can be found in each of the two poem sequences. Karnak is mentioned in both Seventh Elegy and Sonnets II, xxii. The mythology of human transformation into constellations is alluded to in the new stellar configurations of the Tenth Elegy and in the question raised in Sonnets I, xi: "Isn't one constellation called 'rider'?” Just as these constellations form a cosmic counterpart to the figures they have metamorphosed, so poetry itself is understood as a "dual realm" (Sonnets, I, ix). The dual realm is itself doubly present: in the bipartite structure of the Orpheus poems and in the augmentation of the Elegies by the postlude of the Sonnets. In these ambitious works, the poet's personal experiences - unhappiness about years he saw as unfruitful, sorrow over the destruction 
of Duino Castle during the war, and mourning for the young dancer Wera-come together to mourn the passing of an era.

At the same time, both works contribute in remarkable ways to experimental modernism. Duino Elegies pushes language to its outermost borders in its use of innovative imagery, daring intellectual concepts, and rich deployment of metrical forms; the Sonnets explore a range of structural and metaphorical freedom previous unheard-of in that genre. In certain respects, this is not surprising, since Rilke was closely familiar with the French predecessors of twentiethcentury modernism (Baudelaire and Mallarmé), and was following with interest the work of Paul Valéry, whom he came to know personally and some of whose texts he translated into German. In other ways, however, Rilke was not deeply embedded in the modernist movements of the early twentieth century, and although he read Proust with great admiration, he seems to have been unaware of Joyce and Eliot, whose experimental masterpieces Ulysses and The Wasteland were published in February 1922 and October/December 1922 respectively. Rilke's self-imposed isolation over long periods may account for these gaps; but in many other respects he was just as much a learned poet as Eliot. Ranging across a vast spectrum of literature in several languages, Rilke was "enormously widely-read, probably with greater range $[\ldots]$ than his famously learned contemporary Hugo von Hofmannsthal" (Vilain, 143). What accounts for our sense that he differs in some crucial way from T. S. Eliot in this respect? To be sure, his self-presentation as an inspired poet during the period beginning in 1912 is an important factor in this perception. Yet he did not hesitate to write about the books he was reading and to recommend to others those that excited him the most. Most significantly, however, his reading was thoroughly idiosyncratic. Unlike Eliot, who could speak to a group of readers who had shared the literary values and interests of his student days (and who still speaks to those who have, as it were, studied those 
texts by proxy through their reading of The Wasteland), Rilke could not count on a readership that was familiar with his entire repertoire, assembled from such various sources as the library at Castle Duino, boxes of books sent to him by Anton Kippenberg, and other book deliveries from a Zurich bookseller. Rilke gives a telling response to a friend who asked whether it might not be helpful for him to write explanations of the Elegies: while admitting that one might be able to attempt such an exercise, he asks "Where to begin? And am $I$ the one, who can give the Elegies the right interpretation?" (Engel, Kommentierte Ausgabe, vol. 2, p. 600). Rilke's comment is perceptive; but of course, Eliot's notes to The Wasteland were written partly tongue in cheek, and the explanations they provide elaborate an already patent network of citation and allusion. Rilke's Elegies and Sonnets lack the grittiness of The Wasteland, largely because they transform impulses drawn from earlier texts into a complicated set of abstractions. Yet, like Eliot's long poem of 1922, Rilke's Duino project looks simultaneously back at earlier traditions and forward in the direction of modernist innovations. In this respect, Rilke's Duino Elegies and Sonnets to Orpheus are very much of their time: the difficult transition from late nineteenth-century aestheticism to experimental modernism. 